which require congressional action. Apart from these considerations, it is unlikely as a matter of practical politics that the executive would develop any broad plan for determining title to large amounts of property without congressional concurrence. Thus, joint executive-legislative federal action appears the only logical and feasible method of resolving the difficulties in this field.

A beginning was made in the case of the Soviet Union. The executive obtained the Litvinov Assignment, and Congress authorized the President to appoint a commissioner, apparently looking toward a distribution of the funds collected under the Assignment. ${ }^{08}$ Executive and legislative actions must meet the standards of the Fifth Amendment, ${ }^{\mathrm{x} 09}$ but this presents no insuperable difficulties. Congress and the executive should be able to work out a set of rules defining the right of the various types of persons and property affected by delayed recognition. ${ }^{\text {Iro }}$ Legislative-executive regulation of this field on the federal level, is clearly preferable to the shifting, ex post facto determinations of our many-headed judicial system.

\title{
ASSIGNABIITY OF EMPLOYEES' COVENANTS NOT TO COMPETE
}

Covenants of a vendor not to compete with the purchaser of his business and of an employee not to compete with his employer subsequent to his term of employment do not fall within the category of restraints of trade which are void. ${ }^{x}$ A desire to facilitate sales of businesses and the hiring of workers has typically been said to account for the enforceability of covenants ancillary to

${ }^{108} 53$ Stat. II99 (I939). This commissioner was supposed to prove all United States claims against the Soviet Union, but the money to pay his salary was never appropriated and the claims never proved. The money collected under the Litvinov Assignment is still in the United States Treasury. Private Communication from M.P. Shaner, Assistant Legal Adviser to the State Department, Feb. 28, r95r.

rog See discussion notes 77 and 80 supra.

rro The freezing and trade restriction orders, note 98 supra, are a desirable prerequisite to full regulation of this problem.

I All contracts in restraint of trade, even if ancillary, at one time were void. It is certain that if such covenants were contained in a bond by which the obligor undertook to forego the exercise of a trade, they were unenforceable. In Dier's Case, Y.B. 2 Hen. V, pl. 26 (I4I4), the court remarked that if the plaintiff were there, he would go to prison until he paid a fine to the King. The policy that made it desirable that laborers work at some gainful occupation because of the manpower shortage occasioned by the Black Death, dictated that such persons should not be restrained from working. The Statute of Laborers passed in 1349 required every able-bodied man under sixty years of age, not engaged in a trade, tilling land or otherwise profitably engaged "to serve him that doth require him, or else be committed to the gaol." 23 Edw. III c. I ( 1349 ). As the population increased and labor became more mobile, the policy changed. The leading case of Mitchell v. Reynolds, I P. Wms. I8I (K.B., I III), decided that ancillary restraints were valid, at least if partial in their scope. For a general survey of this subject, consult 5 Williston, Contracts $\$ \$ 1634, I 635$ (rev. ed., I937); Dietz, A Political and Social History of England $57-58$ (3d ed., r946). 
such transactions. ${ }^{2}$ In view of this rationale, these covenants will be unenforceable if there is no main lawful transaction, or, there being such a transaction, if the restraint goes beyond what the court considers to be reasonable. ${ }^{3}$ Since restrictive covenants are contrary to a broader policy firmly imbedded in our institutions-the promotion of competition-every extension of their scope should harmonize with that policy. In this light, the question here is whether the employee's covenant is, as some courts have held, so similar to that of the vendor that it too is assignable.

With respect to the vendor's covenant, there is little, if any, dissent from the notion that it may be enforced by one who purchases the business from the original covenantee, even in the absence of express words of assignability. 4 A guarantee that the vendor of a business will not trade on the good will sold along with the tangible assets of the business is said to be indispensable for an effective transfer of the good will. Courts have had no difficulty in saying that for this reason the vendor's covenant is tantamount to an asset of the enterprise, and like other assets assignable when the business is resold. ${ }^{5}$

Greater difficulty is encountered in determining whether the employee's covenant should be similarly assignable. Many of the cases holding such covenants enforceable by the purchaser of a business do not settle the assignability question because the employee continued to work for a time after the sale of the business. Courts in such cases were able to seize upon "ratification" or "recognition" of the purported assignment as a basis for restraining the employee. ${ }^{6}$ This result, however, is frequently supported by assertions that,

${ }^{2}$ Renwood Food Products v. Schaefer, 223 S.W. 2d I44, I5I (Mo. App., I949); Carpenter, Validity of Contracts Not to Compete, 76 U. of Pa. L. Rev. 244, 254 (I928).

${ }^{3}$ See United States v. Addyston Pipe \& Steel Co., 85 Fed. 27 I, 282 (C.A. 6th, I898), aff'd I75 U.S. 2II ( 1899 ), where Judge Taft defined a reasonable restraint as one "ancillary to the main purpose of a lawful contract, and necessary to protect the convenantee in the enjoyment of the legitimate fruits of the contract, or to protect him from the dangers of an unjust use of these fruits by another party."

4 Sickles v. Lauman, I85 Iowa 37 , I69 N.W. 670 (I9I8), annotated in 4 A.L.R. I073 (IgI8); 2 Williston, Contracts $\S 4$ I 2 (rev. ed., I937).

$s$ Representative language is found in Francisco v. Smith, r43 N.Y. 488, 493, 38 N.E. 980,981 ( 1894 ), where the court observed: "Such an agreement is a valuable right in connection with the business it was designed to protect, and, going with the business it may be assigned, and the assignee may enforce it just as the assignor could have enforced it if he had retained the business." Accord: Coker v. Richey, x04 Ore. 14, 202 Pac. 55 I (I92 I); Langendorf United Bakeries, Inc. v. Phillips, 5 Cal. $2 d$ I5o, 53 P. $2 d$ 363 (1936);/Assignability of Contracts in Restraint of Trade, 79 L.J. 2 I9 (I935).

${ }^{6}$ Nelson v. Woods, 205 Ga. 295, 53 S.E. 2d 227 (1949); Blaser v. Linen Service Corp. of Texas, $x_{35}$ S.W. 2d 509 (Tex. Civ. App., I939); Nat'l Linen Service Corp. v. Clower, I 79 Ga. 136, 75 S.E. 460 (1934); cf. Linen Service Corp. of Texas v. Myers, I 8 S.W. $2 d 850$ (Tex. Civ. App., I939). Contra are two cases holding that merely continuing to work for the new employer does not imply assent to the assignment of the employment contract, including the restrictive covenant: Ave. Z Wet Wash Laundry Co. v. Yarmush, x29 App. Div. 427, 221 N.Y. Supp. 506 (S. Ct., I927), aff'd 220 App. Div. 740, 22r N.Y. Supp. 788 (2d Dep't, I927); Oak Cliff Ice Delivery Co. v. Peterson, 300 S.W. ro7 (Tex. Civ. App., I927). 
even in the absence of "ratification," the employee's covenant would be assign. able by analogy to the vendor's covenant. ${ }^{7}$ A recent decision of the Court of Common Pleas of Ohio, Safier's, Inc. v Bialer, ${ }^{8}$ illustrates the way these two lines of argument can be combined to enforce the employee's covenant in favor of the purchaser of the business. In that case, while the court decided that the restrictive covenant was a "transferable asset" and so was enforceable by the plaintiff," it was said, in addition, that even if it were not so assignable, a "novation" occurred when defendant announced his intention to continue in the business.

It is evident that if the employee consents to an attempted assignment of his employment contract, he can not subsequently object that the contract could not be assigned. Such a transaction, however, is not an assignment, but at most is a new contract between the employee and the purchaser of the busi-

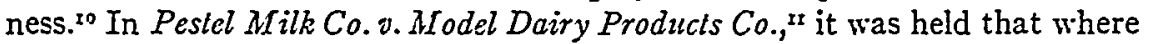
employees refused to sign a new employment contract containing a restrictive covenant similar to that in the original contracts of employment, they could not be bound by ratification although they had continued to work for the purchaser of the business for over half a year..$^{12}$ Such restraint in applying the ratification concept is unusual; many courts hold that merely continuing to work for the new owner implies "ratification" of the assignment of the employment contract. ${ }^{23}$ This looseness is well illustrated by the Bialer case. The employee

iNelson v. Woods, 205 Ga. 295, 53 S.E. 2d 227 (1949); Blaser v. Linen Service Corp. of Texas, 135 S.W. 2d 509 (Tex. Civ. App., 1939); Aat'l Linen Service Corp. v. Clower, r79 Ga. I36, r75 S.E. 460 (1934).

${ }^{8} 93$ N.E. 2 d 734 (C.P. Ohio, I950) (Safier's, Inc. brought an action against Bialer to enjoin him from violating a covenant not to compete so far as customers of the employer were involved, which was included in the employment contract between him and his former employer.)

9 Ibid., at 736-37. While the court here seemed to rely to some extent on words of assignability in the employment contract, where a court is hostile to the enforcement of these covenants by assignees, such words will be given little weight. Thus, it has been stated that "the contract was not made assignable by use of the terms 'assigns,' as same involved a relation of personal confidence which repelled the idea that ... any person other than the one named in the contract ... . should exercise the same." Oak Clif Delivery Co. v. Peterson, 300 S.W. ro7, Iro (Tex. Civ. App., I927). Accord: Paige v. Faure, 229 N.Y. I14, 127 N.E. $89 S$ (1920); MIontgomery v. De Picot, I53 Cal. 509, 96 Pac. 305 (IgoS).

${ }^{20} 4$ Page, Law of Contracts $\S 2258$ (2d ed., I920).

3252 A.E. $2 d 65$ I (Ohio App., I943).

"2 Pestel Millk Co. v. Model Dairy Products Co., 52 N.E. 2d 65I (Ohio App., I943). It should be noted that Pestel Company had frequently solicited these route men to enter into a contract similar to that which they had had with their former employer. To the court, this indicated that plaintifi knew it could not restrain the solicitation of customers without a definite agreement. Another circumstance operating against plaintiff was the fact that the limitation related to a period of six months after the termination of the contract with the former employer, and this had already expired at the time the injunction was sought. One writer has used this case for the proposition that the employee's covenant not to compete cannot be transferred to the buyer of the business without the consent of the employee. I Callman, Law of Unfair Competition and Trade-N Iarks $\$ 64.4$ (b) at 802 (19+5).

"3 Authorities cited note 6 supra; Utilities Ins. Co. v. Stuart, 134 Neb. $413,27 S$ N.IF. 827

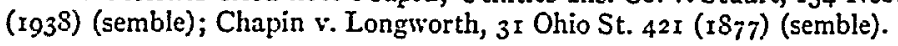


had said that "he would be on the job Monday morning" but changed his mind and never actually worked for the new employer; yet the words alone were held sufficient to bind the employee. ${ }^{x}$ Plainly, it would not be good contract law to say that the "mere talking over" of employment is sufficient to bind the employee to a contract of employment, including a covenant not to compete. ${ }^{55}$

Less ready resort to the ratification fiction would compel courts more squarely to face the question whether the covenant of an employee not to compete is assignable with the sale of the business. That is not to say that then markedly different results would follow, for in the few cases in which this question has been raised in a "pure" form, the covenant not to compete has been held assignable..$^{16}$ Thus, where the employee left the business before it was sold and opened up his own shop, an English court held that the purchaser of the business could enforce the covenant which the employee had made with his employer since it was "part of the good-will" of the business. ${ }^{17}$ Similarly, an American court has held that the purchaser of a business could enforce the restrictive covenant of an employee not to compete or solicit orders despite the fact that the new owner had, upon acquiring the business, fired the defendant. ${ }^{88}$

Implicit in these decisions is the notion that the employee's covenant is an asset of the business, severable from the employee's agreement to work. ${ }^{19}$ Under any other conception of the covenant, assignability would be impossible because where there is a personal contract, such as a contract of employment, ordinarily neither party can assign his rights under it without the consent of the other. ${ }^{20}$ Refusing to accept the view evidently adopted by most American

${ }_{44}$ See Safier's, Inc. v. Bialer, 93 N.E. $2 d$ 734, 737 (C.P. Ohio, I950), where the court stated: "If he accepted employment, even though he did not function, he cannot equitably change his mind and promptly proceed to raid the 'good will' customers of his former employer in violation of his solemn contractual obligation to refrain from so doing."

15 I Williston, Contracts $\$ 39$ (rev. ed., I937).

${ }^{16}$ Torrington Creamery, Inc. v. Davenport, $x_{26}$ Conn. 5x 5 , I2 A. 2d 780 (1940); Benwell v. Inns, 24 Beavan 307 (Ch., 1857); Jacoby v. Whitmore, 49 L.T. 335 (C.A., I883); Baines v. Geary, 35 Ch. D. 154 (1887); Showell v. Winkup, 60 T.L.R. 389 (Ch., 1889); Fitch v. Dewes, [I92I] 2 A.C. 158; Express Dairy Co. v. Jackson, I42 L.T. 23 I (K.B., I929). The English cases seem to be based on dicta originating in an early case where, in considering whether a lifetime restraint on an employee was reasonable as between the original parties, it was said that if the restraint would be valid as long as the master owned the business, it "should be allowed to continue if the master sells the trade." Hitchcock v. Coker, 6 A. \& E. 438,455 (K.B., 1837).

${ }_{77}$ Jacoby v. Whitmore, 49 L.T. 335 (C.A., 1883 ).

${ }_{18}$ Torrington Creamery, Inc. v. Davenport, I-26 Conn. 515, I2 A. 2d 780 (I940).

${ }^{3}$ In Nat'l Linen Service Corp. v. Clower, 779 Ga. $136,142-43$, I75 S.E. 460,464 (1934), the court observed: "[W]e are not concerned with any effort to assign the employee's agreement to work for the employing corporation. It is only the restrictive covenant whereby the employee agreed not to engage in the same line of business, and not to work for any other person engaged in such business for the period of one year within a stipulated territory, that calls for any adjudication...."

${ }^{20}$ Thomas-Bonner Co. v. Hooven, Owens \& Rentschler Co., 284 Fed. 377 (S.D. Ohio, I920); Paige v. Faure, 229 N.Y. II4, I27 N.E. 898 (I920); Ave. Z Wet Wash Laundry Co. v. 
courts that the employee's covenant is a severable asset of the enterprise, a Scottish court observed that since a contract of service could not be assigned because of its personal nature, it was difficult to see how a particular provision of such a contract, the restrictive covenant, could be assigned. ${ }^{2 x}$ That it is the covenant as a separate asset that is being assigned is further demonstrated by the reliance which courts place upon cases involving vendors' covenants, the assignability of which has been justified by calling them assets. No American case has been found to uphold the assignability of the employee's covenant that does not either directly or indirectly rely upon vendor's-covenant cases. ${ }^{22}$

Failure to distinguish between the employee's and the vendor's covenants in regard to their assignability is largely a consequence of a similar confusion concerning their enforceability independent of assignability. While occasionally courts are constrained not to enforce the employee's covenant because of the likelihood that it resulted from an inequality of bargaining power, the majority of American courts overlook the fundamental difference in the policies which presently validate these particular restrictive covenants. ${ }^{23}$

The vendor's covenant has been sustained within limits set by the "rule of reason" because it makes for easier alienability of businesses. ${ }^{24}$ Early English courts sustained the employee's covenant for a similar reason, namely, an in-

Yarmush, I29 App. Div. 427, 22I N.Y. Supp. 506 (S.Ct., I927); Oak Cliff Ice Delivery Co. v. Peterson, 300 S.W. I07 (Tex. Civ. App., I927); I Williston, Contracts $\$ 421$ (rev. ed., I937); 4 Page, Law of Contracts $\$ \$ 225$ I, 2255 (2d ed., I920).

${ }^{2 \pi}$ Berlitz School of Languages, Ltd. v. Duchêne, 6 Scottish Court of Sessions I8r (Ig03).

${ }_{22}$ The court in National Linen Service Co. v. Clower, I79 Ga. I36, x75 S.E. 460 (r934) relied on its prior decisions in Swanson v. Kirby, $98 \mathrm{Ga}$. 586, 26 S.E. 7 I (r896) and Legg v. Hood, I54 Ga. 28, II3 S.E. 642 (I922), both of which involved the assignability of the vendor's covenant. The Clower case in turn was influential in Jones v. Primrose Dry Cleaning Co., I8I Ga. 103, I8I S.E. 577 (r935), in Blaser v. Linen Service Corp. of Texas, I35 S.W. ad 509 (Tex. Civ. App., I939), and in Nelson v. Woods, 205 Ga. 295, 53 S.E. $2 d 227$ (I949). Torrington Creamery, Inc. v. Davenport, I26 Conn. 5I5, I2 A. 2d 780 (I940) relied on Francisco v. Smith, I43 N.Y. 488,38 N.E. 9 r8 (1894), a vendor's covenant case. For good measure, the Bialer decision relied on four of the aforementioned cases, but did not consider the two American cases which have clearly refused to sever the employee's covenant from the employment contract, Oak Cliff Ice Delivery Co. v. Peterson, 300 S.W. ro7 (Tex. Civ. App., r927) and Ave. Z Wet Wash Laundry Co.v. Yarmush, x29 App. Div. 427, 22 I N.Y. Supp. 506 (S. Ct., I927), aff'd 220 App. Div. 740, 22I N.Y. Supp. 788 (2d Dep't, ×927).

${ }_{23}$ Consult 5 Williston, Contracts $\$$ I643 (rev. ed., I937): "If it is rightful to protect a business when it is purchased it should be lawful to protect an established business from injury by an employee, unless circumstances of great hardship exist. The ultimate question should be the same in both cases, - what is necessary for the protection of the promisee's rights and is not injurious to the public." For authority in accord see: May v. Young, I25 Conn. I, 2 A. 2d 385 (1938); Fink \& Sons, Inc. v. Goldberg, Ior N.J. Eq. 644, I39 Atl. 408 (I927); Eureka Laundry Co. v. Long, I46 Wis. 205, I3I N.W. 4 I2 (I9Ir). Consult Cowan, Covenants Not to Compete After Termination of Employment, 5 Peabody L. Rev. 79, 82 (I94x); Validity and Enforceability of Restrictive Covenants in Contracts of Employment, 3I Iowa L. Rev. 249 (1946). But see Rest., Contracts \& 515, Comment (a), (b) (I932).

${ }^{24}$ Authorities cited note 5 supra: 
terest in enabling the craftsman to sell his services. Under the prevailing apprenticeship system, the employer usually gave training as well as wages, and it was felt that he was entitled to assure himself freedom from the competition of skill he himself had created.25 With the increasing use of mass-production methods and the corresponding decline in the skilled trades, the early justification lost much of its force. More and more employees came to their employers either needing no special skill to do the work expected of them, or already having acquired the training needed from public and private educational institutions which became increasingly available to them. ${ }^{26}$ This social change produced a corresponding change in the English law regarding employees' covenants. It was observed by an English court in I920 that

[c]urrent opinion on the relations between employers and employed has moved rapidly in recent years, and thus it is that the House of Lords . . took the opportunity in I9I $3^{27}$ ... to examine the whole problem afresh, with the result that the supreme tribunal ... has now placed upon the permissibility of such covenants a limit which the general interest ... had not previously seemed to require..$^{8}$

In America this social change is reflected in statutes of five states declaring employee's restrictive covenants void, ${ }^{29}$ and by a common-law grow th in a simi-

${ }^{25} \mathrm{~A}$ covenant not to compete in consideration of training to be received frequently was the only condition on which the employer would give the training the employee desired. Consult Horner v. Graves, 7 Bing. 735 (C.P., I831); Hitchcock v. Coker, 6 A. \& E. 438 (K.B., 1837); Mallan v. May, II M. \& W. $65^{2}$ (Ex., I843); Oppenheim, Cases on Federal Anti-Trust Laws 2 (I948).

${ }^{26}$ Consult Enforceability of Contracts Not To Compete After a Term of Employment, 28 Col. L. Rev. 8I (r928).

${ }^{27}$ The court was referring to Mason v. Provident Clothing \& Supply Co., [I913] A.C. 724.

${ }^{28}$ Attwood v. Lamont, [1920] 3 K.B. 57I, 581-582. In Herbert Morris, Ltd. v. Saxelby, [Igr6] I A.C. 688, 702, the court described the limit of the employee's right to protection: "He [the employer] is undoubtedly entitled to have his interest in his trade secrets protected, such as secret processes of manufacture, which may be of vast value. . . He is also entitled not to have his old customers by solicitation or such other means enticed away from him. But freedom from all competition per se apart from these things, however lucrative it might be to him, he is not to be protected against. He must be prepared to encounter that even at the hands of a former employee." For a synopsis of the English law on this point, see Dix, The Law Relating to Competitive Trading $169-74$ ( 1938$)$.

${ }^{29}$ Cal. Business \& Professions Code $\S x 6600$ (Deering, I949); Mich. Stat. Ann. §§ 28.6I28.67 (Henderson, I938); N.D. Rev. Code $\S 9-0806$ (1943); Okla. Stat. tit. I5 § 2x7 (194I); S.D. Code § 10.0706 (I939).

The statutes, in words or substance, provide that every contract by which anyone is restrained from practicing a lawful profession, or engaging in business of any kind, otherwise than is provided by other accompanying statutes which make exceptions in the cases of one selling the good will of a business or of partner or partners anticipating dissolution of a partnership, is to that extent void. See Miller Laboratories, Inc. v. Griffin, 200 Okla. 398, 194 P. 2d 877 (I948), which construes the Oklahoma statute.

The South Dakota code also allows such restraints between duly licensed practitioners. The Michigan statute makes an exception as "to any contract of employment under which the employer furnishes or discloses to the employee a list of customers or patrons, commonly called a route list, within certain territory in which such employee is to work, in which contract the employee agrees not to perform similar services in such territory for [himself or] 
lar direction in a few other jurisdictions. ${ }^{30}$ The minority position is well expressed by a New York court in Kaumagraph Co. v. Stampagraph Co.:

Where ... the employee brings to the employment skill previously acquired, and does not obtain, in the course of his employment, knowledge of methods and processes which are exclusively within his employer's control and right to use, it cannot be said that such a restraint is reasonably necessary to the employer's protection. ... In contradistinction to the sale of a business an employee ordinarily receives no consideration other than the fact of present employment; his labor is a full return for his wage. ${ }^{3 \mathrm{x}}$

In the American jurisdictions adhering to this position, employees will not invariably be permitted to enter into competition with their former employers. The circumstances in which an employee will be restrained are suggested by the words of the New York court in the Kaumagraph case. Thus, where the employee does, in fact, in the course of his employment obtain special knowledge of the employer's processes and customers, he will be enjoined from unfairly using such information in competition with his former master. ${ }^{32}$ This protection is wholly independent of the existence of a restrictive covenant (for such relief is granted in jurisdictions where such covenants are void by statute ${ }^{33}$ ); rather, it results from the exercise of equity's long-recognized power to enjoin

another engaged in a like or accompanying line of business for a period of ninety ( 90 ) days after termination of such contract or services." Mich. Stat. Ann. \$28.66 (Henderson, 1938).

Alabama formerly declared the employee's covenant void, but, as amended, the statute now provides that a vendor or employee may be restrained "from soliciting old customers of such employer within a specified county, city, or part thereof, so long as the buyer or any person deriving title to the good will from him, or so long as such employer carries on a like business therein." Ala. Code, tit. $9, \S 23$ (I940). This section would seem to allow the assignment of the vendor's covenant but not that of the employee.

${ }^{30}$ See Lloyds Employment Corp. v. Kraft, 276 App. Div. ro36, ro36, 95 N.Y.S. 2d 313, 34 (3d Dep't, 1950), where the court said: 'The Special Term denied plaintiffs' application principally on the ground that the negative covenant is valuable only to protect trade secrets and is unavailable to stifle competition. There are no trade secrets in plaintiffs' business and no evidence that defendants have been guilty of any breach of confidence." Kaumagraph Co. v. Stampagraph Co., 235 N.Y. x, I38 N.E. 485 (Ig23); Clark Paper \& Mfg. Co. v. Stenacher, 236 N.Y. 312 , 140 N.E. 708 (1923); Menter Co. v. Brock, 147 Minn. 407, I80 N.W. 553 (I920) (semble); Renwood Food Products v. Schaefer, 223 S.W. 2d I44 (Mo. App., I949) (semble).

${ }^{3 x}$ Kaumagraph Co. v. Stampagraph Co., r97 App. Div. 66, 76, 188 N.Y. Supp. 678, 685 (Ist Dep't, 1923) aff'd 235 N.Y. r, I38 N.E. $5^{85}$ (I923).

32 Hannigan, The Implied Obligation of an Employee, 77 U. of Pa. L. Rev. 970 (I929); McClain, Injunctive Relief Against Employees Using Confidential Information, $23 \mathrm{Ky}$. L.J. 248 (1935); Nims, Unfair Competition and Trade-Marks § 150 ( 1947 ).

${ }_{33}$ Miller Laboratories, Inc. v. Griffin, 200 Okla. 398, I94 P. 2d 877 (r948), annotated in 3 A.L.R. 2 d 522 (I948), noted in 2 Okla. L. Rev. 82 (I949); Jewel Tea Co. v. Grissom, 66 S.D. I46, 279 N.W. 544 (I938); MacKenzie Bread Co. v. Huber, 6o Cal. App. 539, 2r3 Pac. 285 (r929); Glucol Mfg. Co. v. Schulist, 239 Mich. 70, 214 N.W. 152 (1927); Grand Union Tea Co. v. Dodds, I64 Mich. 50, I28 N.W. IOgo (IgIO). The California cases have gone further than those of any other jurisdiction in enjoining the solicitation of former customers in the absence of an express covenant and "may be explained as a successful attempt to evade the provisions .... of the California Civil Code." Employees' Covenants Not to Solicit Former Patrons, 2o Cal. L. Rev. 607, 6I4 n. 29 (I932). 
an employee's betrayal of confidence placed in him by his employer. ${ }^{34}$ In practice, this relief is most freely granted when "trade secrets" are in jeopardy because, it is said, a tangible property right can then be readily discerned; but realization of the underlying impulse to protect against all breaches of the employee's fiduciary responsibilities would seem to require abandonment of the "trade secret" criterion. 35 Were courts to rest their decisions on the fundamental proposition that one should not violate his trust, the absurd necessity of having to distinguish between a written customer list and one committed to memory by the employee would be removed. ${ }^{36}$

This limitation of equitable relief to protection of trade secrets is, of course, one reason employers insert restrictive covenants in employment contracts. However, where such covenants are given effect, not only is protection against an employee's breach of trust made more certain, but the covenant may extend farther and prohibit competition involving no departure from ordinary fiduciary principles. This is so because courts are then dealing with a restriction which by its terms is not limited to the exploitation of knowledge properly belonging to the employer. All competition is forbidden if the restraint is "reasonably necessary to secure the protection of the business or good will of the employer." 37 Since this is the same test of enforceability applied by courts to the vendor's covenant which is designed to inhibit competition with the transferred business, ${ }^{38}$ it is clear that the result is to obscure the distinction between the two types of covenants. The employer may be protected against an em-

34 Authorities cited note 32 supra. In Du Pont Powder Co. v. Masland, 244 U.S. I00, 102 (I9I7), Justice Holmes stated: "The word property as applied to ... trade secrets is an unanalyzed expression of certain secondary consequences of the primary fact that the law makes some rudimentary requirements of good faith.... The starting point... is not property or due process of law, but that defendant stood in confidential relations with plaintiff."

${ }_{35} \mathrm{McClain}$, Injunctive Relief Against Employees Using Confidential Information, $23 \mathrm{Ky}$. L.J. $248,254^{-255}$ (I935), suggests that the relationship originates in a fundamental doctrine of equity that a person shall not use a confidential relationship at the expense of the other.

${ }^{36}$ The employee was not restrained, in the absence of a written list of customers in Progress Laundry Co. v. Hamilton, $208 \mathrm{Ky} .348,270$ S.W. 834 (1925) and Woolley's Laundry, Inc. v. Silva, 304 Mass. 383, 23 N.E. 2d 899 (r939), noted in 37 Mich. L. Rev. 505 (r939). Contra: Colonial Laundries, Inc. v. Henry, 48 R.I. 332, 138 Atl. 47 (I927). The employee was enjoined from soliciting customers named on a written list in Todd Protectograph Co. v. Hirschberg, I00 N.Y. Misc. 4I8, r65 N.Y. Supp. 906 (S. Ct., I9I7) and Andrews Co. v. Friedman, 26 Pa. Dist. R. 843 (I9I7).

37 Chemical Fireproofing Corp. v. Krouse, r55 F. 2 d 422, 423 (D.C., I946). In a footnote the courtindicated that, in general, courts have not accepted the standards for judging the "reasonableness" of restrictions incident to the sale of a business as determinative in the personal service case. Ibid. But the test of reasonableness is evidently to be retained. Consult authorities cited note 40 infra. If an employer is "unreasonable" in his clause of restraint, some courts will enforce it only as to the "reasonable" amount while others will deny all relief, on the theory that " "like the dog in the fable, they grasp too much and so lose all." "Herreshoff v. Boutineas, ${ }_{7} 7$ R.I. 3 , 7, I9 Atl. 7I2, 713 ( 8890 ). Consult Noe v. McDevitt, 228 N.C. 242 , 45 S.E. $2 d$ I2I (I947), noted in 26 N.C.L. Rev. 402 (I948). On the general subject, consult Fox, The Law of Master and Servant I27-I34 (I950).

${ }^{38}$ Williston, Contracts $\$ 164$ I (rev. ed., r937). 
ployee's competition although no trade secret or breach of fiduciary duty is involved. While some courts reach what is in effect a sound result by including in the "reasonable" category only such restraints as would be enforceable by ordinary fiduciary rules, ${ }^{39}$ for most courts the issue is not whether the employee has departed from fiduciary standards but whether the restraint imposed is one reasonably calculated to protect the business..$^{\circ}$

Thus, as between the parties, the employee's covenant in many American jurisdictions is enforced in a manner quite similar to that of the vendor. Overlooked in this process is the change in "relations between employers and employed" that has been recognized in a few American states. The employer is in many cases protected against competition which is in no way intensified by knowledge he has imparted to the employee.

With the employee's covenant thus recognized as a bulwark against competition to the business, courts have not hesitated to analogize it to the vendor's covenant, and so to regard it as an assignable asset of the enterprise. ${ }^{\mathrm{I}}$ The anomalous result ensues that a portion of a nonassignable personal contract is frequently held assignable by American courts. If in the first instance enforcement of the employee's covenant were restricted to enjoining breaches of trust, ${ }^{42}$ which is all that remains of its original underlying justification, courts might not so freely characterize it an asset. "Ratification" aside, enforcement by an assignee would be more limited.43

39 Renwood Food Products v. Schaefer, 223 S.W. 2 d I44, 152 (Mo. App., I949); Super Maid Cook-Ware Corp. v. Hamil, 50 F. 2d 830 (C.A. 5th, I93I); Club Aluminum Co. v. Young, 263 Mass. 223, I60 N.E. 804 ( $\mathrm{r}_{928}$ ). Some courts have limited the scope of the covenant by suggesting that since the services of the defendant were not unique, an injunction should be refused, extending the rule of Lumley v. Wagner, r De G. \& S. 604 (Ch., I852). Under that theory, in the absence of trade secrets or lists of customers, the restraint would be rarely enforced. Menter Co. v. Brock, I47 Minn. 407, I80 N.W. 553 (I920); Sternberg v. O'Brien, 48 N.J. Eq. 370, 22 Atl. 348 (r89I). Most courts, however, deem the uniqueness of defendant's services as immaterial, since the question involved is one of restraint of trade after employment and not one of "indirect specific performance" during the term of employment. Hollander \& Son v. Imperial Fur Blending Corp., 2 N.J. 235, 66 A. 2d 3I9 (r949); National Linen Service Corp. v. Clower, I79 Ga. I36, I75 S.E. 460 (1934). But see Pound, The Progress of the Law, 33 Harv. L. Rev. 420, 440 (rg20), where it is suggested that the same considerations apply to covenants of an employee during his service as afterwards, and the test would thus be whether breach of the negative involves a damage by itself apart from or over and above breach of the negative.

${ }^{40}$ Consult the numerous cases collected in Validity and Enforceability of Restrictive Covenants, 9 A.L.R. 1456 (I920); 20 A.L.R. 86x (I922); 29 A.L.R. I33I (r924); 52 A.L.R. I363 (I928); 67 A.L.R. I002 (1930); 98 A.L.R. 963 (I935); IIg A.L.R. I452 (I939).

42 Consult authorities cited note 22 supra.

42 This proposal is neither radical nor novel. Consult the Enforceability of a Promise Not to Compete After An Employment At Will, 29 Col. L. Rev. 347, 352 (x929); Employee's Covenant Not to Solicit Former Patrons, 20 Calif. I. Rev. 607 (I932), noting Shreveport Laundries, Inc. v. Teagle, I39 So. 563 (La. App., I932).

43 It has been held that a trade secret entitles the assignee to enjoin those who have held confidential relations with the assignor, though they may never have had any connection with the assignee. Vulcan Detinning Co. v. American Can Co., 67 N.J. Eq. 243, 58 Atl. 290 (rg04). But this is a theory quite different from relying on the restrictive covenant as a separate assignable asset and one much narrower in scope. 